\section{DE DE GRUYTER} OPEN
Journal of Intercultural Management Vol. 5, No. 3, September 2013, pp. 5-11 DOI 10.2478/joim-2013-0014

Łukasz Sułkowski

Społeczna Akademia Nauk

\title{
Strategic Management as the Ideology of Power
}

\begin{abstract}
The purpose of this paper is to present the key themes of strategic management from the perspective of Critical Management Studies [More: Sułkowski, 2012]. Strategic management seen as the most advanced and sophisticated form of targeting reseved only for the elite top menagement is interpreted by critical scholars as an ideology of power exercised by elites. The article presents the analysis of the foundations of the $\mathrm{CMS}$, and then puts these issues in the field of strategic management.
\end{abstract}

Key words: Critical Management Studies, CMS, Crtitics of Strrategic Management

\section{Introduction}

Critical management trend (Critical Management Studies) takes reflection on the functioning of key dilemmas of modern organizations. It is the orientation located in a group of alternative paradigms, criticizing the dominant neopositivist-functionalist approach [Sułkowski, 2004]. Management sciences are treated by the researchers who identify themselves with the CMS, as the discourse involved in the valuation. Undertaken critical topics concern: managerism ideology, oppressive organization, „false consciousness“, „symbolic violence“, and many other aspects of management with far-reaching moral consequences.

The purpose of this paper is to present the key themes of strategic management from the perspective of Critical Management Studies [More: Sułkowski, 2012]. Strategic management seen as the most advanced and sophisticated form of targeting reserved only for the elite top management is interpreted by critical scholars as an ideology of power exercised by elites. The article presents the analysis of the foundations of the CMS, and then puts these issues in the field of strategic management. 


\section{CMS Paradigm}

Critical Management Studies are a relatively new perspective, which crystallized at the beginning of the 90's of the twentieth century. Pioneering works undertaking the issue of ideological demystifications and management functions based on domination structures appeared already in the 70s [Braverman, 1974]. However, in the last two decades, the critical management studies (CMS) took the form of institutionalized discourse, through: a series of publications, research, conferences, journals, and environmental [Alvesson, Willmott (eds.), 1992].

Reconstruction of the key tenets of the most significant assumptions of critical studies allows to find some common assumptions forming the internally differentiated paradigm of Critical Management Studies. First of all, it means treating the management science as a persuasive discourse arising from the assumptions of capitalism and aiming at sustaining the status quo based on domination and exploitation. Critical management studies trend has disclosing ambitions leading to question the seemingly "objective" and "natural" status: of corporate order, management power, institutions, practices and identity of management [Alvesson, Willmott, 2003]. This "de-naturalization" of managerialism discourse leads to a description of activities and institutions based on domination, oppressive, often harming people and society, and hiding under the guise of rationality, management sciences. The postulate of exploring the interests of different social groups executing power by controlling the discourse of science is to perform as a consequence to the criticism and changing the existing, unjust social order. As a result of the development of the critical approach disadvantaged groups, and therefore subject to possession, such as ethnic and social minorities, women, would build their awareness and would be able to express and realize their interests. Tools developed by the critical trend include: deconstruction and de-naturalization of managerial discourse, critical and reflective analysis of the language of executing power, methods of strengthening the autonomy and self-control of disadvantaged groups (e.g. empowerment) [Parker, 2002]. Key themes emerging in the critical management studies include:

- the issue of emancipation of disadvantaged groups in organizations

- revealing camouflaged relationships of domination and exploitation in the management,

- describing instrumentalism in managerial approach to a human

- indicating mechanisms of the violence and symbolic violence in organizations,

- demystification of ideological discourse functions of management, particularly in relation to human resource management, marketing, strategic management 
- analysis of neo-imperial, unethical and socially irresponsible managerial practices arising from the instrumentalism of managerial reason [Grey, Willmott, 2005].

\section{Management as legitimization of dominance}

Business schools "enslave the minds" of managers and employees by providing them with sources of identity. Identification with a seemingly scientific, objective, efficient, fair, and in general, according to management advocates the only possible system of governance in the modern world, leads to false consciousness. False consciousness, according to the concepts of critical studies, is produced by the system in favor of the dominant social group. It is a tool of control and "symbolic violence". Huge masses of people volunteer their time to an absurd pursuit of new things and services giving impetus to the development of transnational corporations, owners and top managers, i.e. those at the top of the pyramid. False consciousness does not affect then managers only, giving them unjustified sense of mission and justice while exercising power in the interest of the organization, but also the employees and consumers who give in to the power symbolic violence called by S. Deetz the "colonization of everyday life by the corporations" [Deetz, 1995].

Management does not create a single paradigm, the combination of theory and methodology, but it is a kind of "jungle" of different concepts. "Life cycle" of these concepts is shortened more and more. Many of them become a mere passing fashion promoted by "management gurus", consulting firms or academic institutions. These concepts typically are not based on research, but in majority of cases on one impressive idea, which leads to the simplification of the organizational reality. Studies in the management of fashion show both the rapid dissemination of ideas and a very quick abandonment by the organization and management theoreticians [Abrahamson, 1991, p. 586-612]. Fashionable "theories" make management sciences more popular, but also less reliable. They are an excellent example of social constructivism, in which the concept impact back the organizational reality [DiMaggio, Powell, 1983, p. 147-160].

\section{Management as ideology of power}

Management sciences became in the twentieth century an influential discipline, closely linked to business and government circles. In the institutional field management sciences have developed various interest groups which force their own influence giving thus shape to the management sciences themselves. The most important interest groups will include: scientists specializing in the management, business consultants and advisers, businessmen, entrepreneurs and owners. "The stakes in the social game", whose arena are also the management sciences include: money, social prestige and power. One could 
also point out other social divisions such as managers in the private sector and public sector management or national divisions of workers, and other forms of "stakes in the social game" such as a sense of security. The interests of these groups intersect to form a complex constellation of more or less permanent coalitions interacting consciously or subconsciously. Often behind the veil of objectivity, the interests of social groups involved in the social game, which takes place also in the area of management sciences, can hide.

Managers are nowadays one of the most influential social groups. They control the flow of funds, goods and services on a global scale. They exercise power in the majority of social structures, small and large groups of people pushing politicians aside. As a dominating group, managers create their own ideology that allows capture the power and rationalize their own position. Managerism ideology contributes to the creation of identity and group solidarity. It finds reflection in the object concepts and management methods developed in the framework of the dominant trend.

\section{Strategic Management in Alternatives Paradigms}

Strategy is a cultural construction, which means that in its formation and implementation the culture participates together with its value system and criteria for rationalism, standards and stereotypes. The strategy must be socially explained and communicated. Strategies are social and they should be formed on the basis of the assumption of limited rationality, which results from the limited access to information as well as the significant influence of social factors, in which the organizations are immersed. For such a strategy the understanding of authority structures and communication is crucial. The organizational strategy is, then, the reflection of interdependence between the socialand economic subjects. Interpretative strategyis assumed to beambiguous, relative and ideological. It is based on creative and heuristic processes, which cannot be put into algorithms. The game metaphor, in which the element of uncertainty is important, determines the area of strategy formation which is based on the postulate of limited rationality. The war metaphor brings to our minds ideological and emotional components, while the comparison of the strategy to the language game focuses on interpretation processes of the social actors. In the understanding of a strategy, irrational elements can be found which convinces us that organizational reality is not given but it is being constructed by managers and other social subjects during their interactions. Brusson promotes the interpretative approach based on decisional irrationality, according to which rational decisions do not always support effective actions [Brusson, 1985, p. 22]. A researcher can have doubts, while a manager should quickly make his decision, communicate it without any hesitation, persuade others to do it and implement it wholeheartedly. If we stress only the rationality of decisions, then often the more 
important elements of involvement, communication and leadership may suffer. Clarke points out the dangers related to the formation of plans with a symbolic dimension. They can make the managers less alert, indicating that everything is recognized and under control [Clarke, 1999]. According to the social constructivism assumptions, the border between descriptive and normative understanding of strategy is vague. Management practice acknowledges that strategy is more often interpreted retrospectively than planned prospectively. Therefore, the actions are not the consequences of the planning process but they are intertwined with the interpretation processes of the organizational reality.

\section{Strategic management as the quintessence of managerial ideology}

CMS researchers take many critical topics relating to strategic management. Above all, they treat strategic management as a kind of essence of managerial ideology that rationalizes instrumental, unfair, and often socially harmful actions taken by management organizations. Among the many topics of critical perspective on strategic management there are three main areas of ethical dilemmas, namely: ideology managerism, „symbolic violence“, and the instrumentalisation of human actions.

Managerism ideology constituting the "false consciousness" of both subordinates and managers justifies the apparent obviousness and naturalness of the existing social order and organization. Thus it constructs the identity of managers and employee acting as reflection of power relations and inequalities. It acts as a camouflage for the real, unjust social order.

Strategy becomes a tool of "symbolic violence" that instrumentally channels human activities in the organization, leading to their focus on profits, and eliminating the moral sphere of the area of interest of management [Jacques, 1996]. This means that management of organizations can rationalize the lack of sensitivity to the problems of people focusing solely on the instrumental purpose of the organization imposed by the system and the structure of ownership. The strategy can be seen through the prism of critically interpreted social practices, namely: communication activities, forms of organizational culture and demonstration of power [Vaara, Sorsa, Pälli, p. 685-702]. In the social practices belonging to the area of strategy there reveal such elements as instrumentalism approach to human domination practices through profit and commercialization, practices of domination and masculinism [Hendry, 2000, p. 955-977; Alvesson, Mats i Deetz, Stanley, 2005, p. 60-106].

Strategy understood as a discourse is developing a 'language game' based on a kind of "meta-narratives" that refers to the belief in possibilities: prediction of the development of the organization and the market operation, effective management and leadership [Cunliffe, p. 351-371, Monin, 2004]. It is therefore 
a kind of discourse about a self-fulfilling prophecy [Samra-Fredericks, 2005, p. 803-841]. Strategic management justifies its own value and importance in the management sciences "spinning tales" about his own greatness [Kornberger, 2011, p. 136-162]. Strategy interpreted in terms of political economy examines neomarxist- interpretive dependency between economics and politics. In this sense, it is the position of the economy rather than management, according to which engagement of the economy with politics creates and perpetuates the principles of allocation of resources, the use of profit and exploitation of people reflecting the capitalist social order and power relations [Alvesson, Willmott, 2002, p. 619-644].

\section{Summary}

The last fifteen years have seen the field of CMS grow to increasing importance as an alternative not only to mainstream research but also teaching on management and organization. A critical look at the strategic management is a crucial aspect of Critical Management Studies.

In spite of a growing interest in epistemological, praxeological and axiological issues there is still a visible lack of critical reflection in the context of strategic management.

Emerging fundamental scientific and practical problems are: instrumental and oppressive approach to people in the organization, dehumanization of management and manipulation serving to increase benefits of those in power in organizations. Strategic management is also a kind of ideology of those in power in organzations, which serves as a rationalization unethical activities and allows to get rid of ethical dilemmas.

The industrial era of dehumanization of the workforce has influenced and left management practices being incompatible with the emotional, cognitive and collaborative underpinnings of modern human capital. If management has been dehumanized, there is a need to humanize it again. Management should be returned to its roots in the humanities and the liberal arts. There is a need to re-establish people and moral purpose as the center of gravity based on which management is practiced. In order not to surrender to the negative elements in liberalism, corporatization and globalization, the need for strategic thinking in those areas of CMS is greater than ever before [more about: Sulkowski, 2013].

\section{Bibliography}

Abrahamson E., Managerial Fads and Fashions: the Diffusion and Rejection of Innovations,

"Academy of Management Review", nr 16/3, 1991, p. 586-612.

Alvesson M., Willmott H. (eds.), Critical Management Studies, London: Sage 1992.

Alvesson M., Willmott H. (eds.), Studying Management Critically, London: Sage 2003. 
Alvesson M., Willmott H., Identity regulation as organizational control: producing the appropriate individual. "Journal of Management Studies". Nr 39/5, 2002, s. 619-644.

Alvesson, Mats i Deetz, Stanley. 2005. Critical Theory and Postmodernism: Approaches to Organization Studies. [w:] Chris Grey i Hugh Willmott (red.). Critical Management Studies. A Reader. Oxford: Oxford University Press, s. 60-106

Braverman H., Labor and Monopoly Capital: The Degradation of Work in the Twentieth Century, New York: Monthly Review Press 1974.

Brusson N., The Irrational Organisation: Irrationality as a Basis for Organizational Action and Change, John Wiley, Chichester, 1985, p. 22.

Clarke L., Mission Improbable: Using Fantasy Documents to Tame Disaster, University of Chicago Press, Chicago, 1999.

Cunliffe A.L., Managers as practical authors: Reconstructing our understanding of management practice, Journal of Management Studies, 2001, 38, 3, pp. 351-371.

Deetz S., Transforming Communication, Transforming Business: Building Responsive and Responsible Workplaces, Cresskill, Hapton 1995.

DiMaggio P.J., Powell W.W., The Iron Cage Revisited: Institutional Isomorphism and Collective Rationality in Organizational Fields, "American Sociological Review", nr 48, 1983, s. 147-160.

Grey C., H.C. Willmott, Critical Management Studies: A Reader, Oxford University Press 2005.

Hendry J., Strategic decision making, discourse, and strategy as social practice, Journal of Management Studies, 37, 7, 2000, pp. 955-977.

Jacques R., Manufacturing the employee: management knowledge from the $19^{\text {th }}$ to $21^{\text {st }}$ centuries, Sage Publications, 1996.

Kornberger M., Strategy as performative practice: The case of Sydney 2030, Strategic Organization, 1 Maj 2011, 9, s. 136-162.

Monin N., Management Theory. A Critical and Reflective Reading, Routledge, London New York 2004.

Parker M., Against Management: Organisation in the Age of Managerialism, Oxford: Polity 2002.

Samra-Fredericks D., Strategic Practice, 'Discourse' and the Everyday Interactional Constitution of 'Power Effects', "Organization", November 2005; vol. 12, 6, s. 803-841.

Sułkowski Ł., Epistemology of Managment, Peter Lang International, Frankfurt-BerlinBern-Vien-Oxford-New York-London-Warsaw, 2013.

Sułkowski Ł., Epistemologia i metodologia zarzq̨dzenia, PWE, Warszawa 2012.

Sułkowski Ł., Neopozytywistyczna mitologia w nauce o zarzq̨dzaniu, w: „Organizacja i kierowanie", nr 1 (115), 2004.

Vaara E., Sorsa V., Pälli P., On the force potential of strategy texts: a critical discourse analysis of a strategic plan and its power effects in a city organization, "Organization", November 1, 2010, 17, s. 685-702. 